\title{
Factors affecting public housing credit choice of sharia property developer in Central Java
}

\author{
Nurzahroh Lailyah
}

Faculty of Economics, Universitas Sunan Muria, Indonesia

\begin{abstract}
Purpose - This study analyses the various factors that affect the probability of consumers choosing public housing credit $(\mathrm{PHC})$ of Sharia Property Developer (SPD) in Central Java.
\end{abstract}

Method - The data of this study are primary data obtained through questionnaires to 252 people from a population of 1,269 PHC SPD consumers in Central Java (Boyolali Regency, Magelang Regency, Pati Regency, Semarang City, and Wonosobo Regency). Furthermore, consumer data were analysed using a binary logit regression model with SPSS software.

Result - The results of this study state that the variable price and religiosity have a significant negative effect on the probability of choosing a PHC in Islamic Property Developer. In comparison, the variables of income, location, and facilities do not significantly affect the likelihood of selecting a PHC on a Sharia Property Developer. Wonosobo Regency is the region with the most significant probability of choosing a PHC on a Sharia Property Developer compared to Boyolali, Pati, Magelang, and Semarang City Regencies. Meanwhile, Pati Regency is the region with the least probability of choosing a PHC as a Sharia Property Developer.

Implication - The Central Java SPD can use the finding of this research to consider the evaluation and improvement of PHC products in the future. So that consumers do not turn to competitors, have more confidence, and are satisfied with Sharia Property Developer services.

Originality - The originality of this research lies in the object under study, test analysis, and research location.

Keywords: public housing credit, sharia property developer, price perception, location perception, consumer perception, perception of religiosity, Central Java, Indonesia 


\section{Introduction}

The emergence of alternative sharia mortgage offers a system without involving the bank. Bankless sharia public housing credit (PHC) was motivated by Rosyid Aziz, later named the founder of SPD in 2008. The idea of $100 \%$ sharia PHC that he promoted was: no bank, no usury, no fines, no confiscation, no insurance, no problematic contracts, and without bi-checking. For people who know the importance of compliance with sharia, this idea is an alternative way to carry out $100 \%$ sharia mortgage transactions. Even though the ideas he was promoting were still relatively new, they were developing very rapidly in Indonesia, one of which was Central Java.

Sharia Property Developers in Central Java just started their business in 2016. Therefore, property developers in Central Java occupy the most significant position. Still, based on data on sales of housing units on credit, it shows an unstable fluctuation in sales with a trend that tends to decrease from 2016 to 2017. The author interviewed the Director of Sharia Property Developer of Semarang City. Graph 1 contains the result of the interview, and it shows that the demand for housing on a mortgage basis for Sharia Property Developers in Central Java is unstable.

In the prediction of SPD 4 years ago, home sales on a mortgage basis will continue to increase in line with the projected population growth rate for Central Java from 2015 to 2020, which

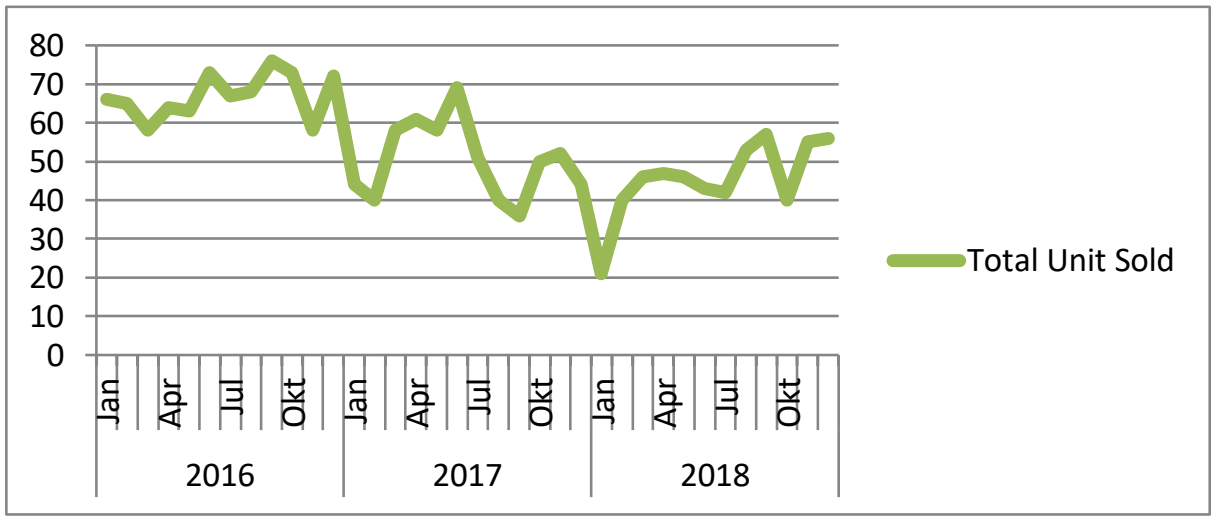

Figure 1. Summary of Monthly Mortgage Sales Reports (in units) of Sharia Property Developers in Central Java 
will increase by $51.3 \%$ (Central Bureau of Statistic of Indonesia about Population Projection, 2015).

In the prediction of SPD 4 years ago, home sales on a mortgage basis will continue to increase in line with the projected population growth rate for Central Java from 2015 to 2020, which will increase by $51.3 \%$ (on the website of BPS Indonesian Population Projection, 2015). This increase is what the researchers considered the underlying of the study, namely analyzing the factors that influence the demand for mortgages at SPD in Central Java. Understanding the factors will contribute to better future mortgage products.

\section{Literature review}

In this regard, several studies have analyzed the factors that influence consumers' decisions to choose mortgages. Budi (2009) studied housing demand in Semarang and found that the factor influencing housing demand is house prices. Based on the results of his research, it turns out that the house price factor has the most dominant influence on housing demand. Fifilia (2009) found a significant positive effect of product, price, promotion, and location on home purchasing decisions. Research by Djaja (2010) found that the factors that influence consumer decisions to buy a house, namely 7P (product, price, promotion, personal traits, physical evidence, and process), and all of these factors have a positive and significant effect on the decision to buy a house.

In Blitar, Suprajang (2011) researched the factors that influence consumers to buy a house. Multiple linear regression analysis with full regression using the F-test, simultaneously the product, promotion, price, and place variables together significantly affects. Against the buyer's decision (Suprajang, 2011). Mahardini and Woyanti (2012) researched Semarang, finding the results in their study that income, price, and place variables positively and significantly affected housing demand. Wardani (2013) researched Jakarta and found that not all variables in the promotion mix affect the decision-making for financing products PHC. Only the sales promotion variable and the publicity variable significantly affect the decision to make mortgage financing products. Meanwhile, the advertising and personal selling variables did not affect the decision taking PHC (Wardani, 2013). 
Radiah (2014) examined the factors that influence a customer's decision to take a mortgage loan in Samarinda. In particular, in the marketing mix of service companies, some elements or elements become the basis for consideration in making decisions marketing communication, namely 4P plus 3P: product, price, place, promotion, people, process, and physical evidence. The analysis results obtained are Product, Price, and Process variables that significantly affect mortgage purchase decisions. In contrast, other variables have an insignificant effect (Radiah, 2014). The findings show that price, promotion, people, and physical evidence are significant with customer perception. Ismail (2014) researched 160 respondents with the conclusion that the factors had a significant positive effect on the election decision Islamic home financing, namely advertising.

Luthfi analyzed the effect of the marketing mix on home purchase decisions. The results showed that together the product, price, promotion, and location had a positive and significant impact on purchasing decisions in buying a house (Luthfi, 2017). In Banjarbaru, Jumiati (2017) showed that the price variable had a significant positive effect on home purchase decision. On the other hand, Hidayat (2017) conducted research using multiple linear regression analysis. In contrast, the results of his study show that marketing variables have a significant influence on customer decisions in submitting mortgage applications.

In the same year, in his research, Khoirudin (2017) concluded that prices had a significant negative effect on the number of mortgage requests. Amri's research on 50 respondents concluded that for conventional and sharia mortgage respondents, product, price, promotion, and location variables for conventional and sharia mortgage respondents had a positive and significant effect on customer decisions (Amri, 2018). Product, price, promotion, and place variables significantly positively affect home purchase decisions (Primarianto, Yuliati \& Affandi, 2018). For this study, the researcher specifically uses income, price, location, facilities (physical evidence), and religiosity as variables that influence consumer decisions to choose PHC at SPD in Central Java. 


\section{Methodology}

Primary data in this study are consumers that choose PHC on SPD in Central Java $\left(n_{1}\right)$ with total population of 1269 and consumers do not choose PHC on SPD in Central Java $\left(n_{2}\right)$ with unknown total population. Meanwhile, secondary data was obtained through documentation from official sources: SPD Ar-Royan Semarang, SPD Grand Syafa Madina Magelang, SPD Pesona Asri Wonosobo, SPD Samawa Residence Boyolali, and SPD Taylon Sejahtera Pati.

The location of this research is the SPD (Sharia Property Developer) office in the Central Java region, covering Semarang City, Magelang Regency, Wonosobo Regency, Boyolali Regency, and Pati Regency. Authors selected these locations because the number of project units is more than 100. (In other locations, the number of project units is less than 100 , meaning that 5 (five) areas have carried out more PHC transactions than other locations).

The sampling technique for consumers to take PHC SPD $\left(n_{1}\right)$ and consumers not to take PHC SPD $\left(n_{2}\right)$ uses a purposive sampling technique, namely the sampling technique with certain considerations (Sugiyono, 2013). Researchers used the cluster sampling technique (sample area), this is because the data source is very broad, namely in the province of Central Java. The sample areas are Semarang City, Magelang Regency, Wonosobo Regency, Boyolali Regency, and Pati Regency. Each region was taken $10 \%$ representative as the research sample.

The analysis in this research will be carried out in the form of descriptive analysis and quantitative analysis. Descriptive analysis is needed to illustrate that consumer decisions are influenced by internal factors (within the consumer) and external factors (external conditions of the consumer). This depiction can be useful in formulating a policy related to the development of Sharia Property Developers, especially in this research. The quantitative analysis in this study uses binary logit regression, with the hypothesis test analysis technique using the log-likelihood function ratio test.

For measurement, if the sample chooses a Sharia Property Developer PHC, it is worth 1 . While the value is 0 if the sample does not choose PHC on a Sharia Property Developer, or it is written as follows: 


$$
\begin{aligned}
& Y=1 \text { (Choosing a PHC in a Sharia Property Developer) } \\
& Y=0 \text { (Don't Choose a PHC onSharia Property Developer) }
\end{aligned}
$$

The research model is as follows:

$$
\operatorname{Ln}=\left(\frac{\mathrm{Pi}}{1-\mathrm{Pi}}\right)=\mathrm{a}+\beta_{1} \mathrm{X}_{1}+\beta_{2} \mathrm{X}_{2}+\beta_{3} \mathrm{X}_{3}+\beta_{4} \mathrm{X}_{4}+\beta_{5} \mathrm{X}_{5}+\mathrm{e}
$$

Information:

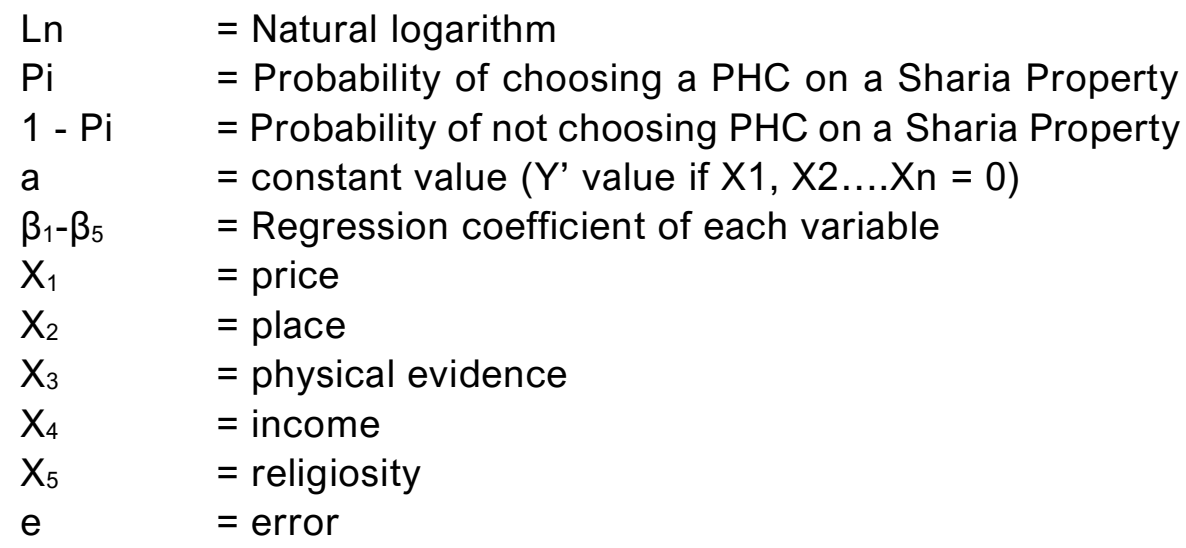

\section{Results and discussion}

Table 1 shows the descriptive data analysis of all main variables. Respondents came from Boyolali Regency, Magelang Regency, Pati Regency, Semarang City and Wonosobo Regency. The gender of the respondents is relatively balanced between the number of men and women. Most respondents' income was in the category below $7,600,000$ at $73 \%$. For the perception of the price of a Sharia Property Developer PHC, 38.1\% considered it standard, $37.7 \%$ thought it expensive, and $24.2 \%$ considered it cheap. As for the perception of the religiosity variable, more than $50 \%(56.3 \%)$ considered PHC on Sharia Property Developers halal, and $22.2 \%$ considered it syubhat, and $21.4 \%$ considered it haram (forbidden).

The Chi-Square table value for DF 8 (Number of independent variables - 1) at the 0.05 significance level is 15.507 because the value of Chi-Square Hosmer and Lemeshow has calculated as 6.802 $<$ Chi Square table 15.507 or a significance value of $0.558(>0.05)$ so that $\mathrm{HO}$ is accepted. The result indicates that the model is 
Factors affecting public housing credit choice...

Table 1. Identity of respondents and variables

\begin{tabular}{|c|c|c|c|c|}
\hline Variable & & Frequency & Percent & Cumulative \\
\hline \multirow[t]{2}{*}{ Gender } & Female & 121 & $48.0 \%$ & $48.0 \%$ \\
\hline & Male & 131 & $52.0 \%$ & $100.0 \%$ \\
\hline \multirow[t]{3}{*}{ Income } & $<7.600 .000$ & 184 & $73.0 \%$ & $73.0 \%$ \\
\hline & 7.600.000-19.000.000 & 65 & $25.8 \%$ & $98.8 \%$ \\
\hline & $>19.000 .000$ & 3 & $1.2 \%$ & $100.0 \%$ \\
\hline \multirow[t]{3}{*}{ Price } & Cheap & 61 & $24.2 \%$ & $24.2 \%$ \\
\hline & Standard & 96 & $38.1 \%$ & $62.3 \%$ \\
\hline & Expensive & 95 & $37.7 \%$ & $100.0 \%$ \\
\hline \multirow[t]{3}{*}{ Location } & Near & 117 & $46.4 \%$ & $46.4 \%$ \\
\hline & Moderate & 131 & $52.0 \%$ & $98.4 \%$ \\
\hline & Far & 4 & $1.6 \%$ & $100.0 \%$ \\
\hline \multirow[t]{3}{*}{ Facilities } & Agree & 228 & $90.5 \%$ & $90.5 \%$ \\
\hline & Neutral & 24 & $9.5 \%$ & $100.0 \%$ \\
\hline & Disagree & 0 & $0.0 \%$ & $100.0 \%$ \\
\hline \multirow[t]{3}{*}{ Religiosity } & Halal & 142 & $56.3 \%$ & $56.3 \%$ \\
\hline & Syubhat & 56 & $22.2 \%$ & $78.6 \%$ \\
\hline & Haram & 54 & $21.4 \%$ & $100.0 \%$ \\
\hline \multirow[t]{5}{*}{ Regency/City } & Boyolali & 82 & $32.5 \%$ & $32.5 \%$ \\
\hline & Magelang & 34 & $13.5 \%$ & $46.0 \%$ \\
\hline & Pati & 48 & $19.0 \%$ & $65.1 \%$ \\
\hline & Semarang & 28 & $11.1 \%$ & $76.2 \%$ \\
\hline & Wonosobo & 60 & $23.8 \%$ & $100.0 \%$ \\
\hline
\end{tabular}

JIEMB | 73

acceptable. Hypothesis testing can be done because there is no significant difference between the model and its observation value.

The Chi-Square value for DF 8 (Number of independent variables - 1) at the 0.05 significance level is 15.507 because the value of Chi-Square Hosmer and Lemeshow has calculated as 6.802 $<$ Chi Square table 15.507 or a significance value of $0.558(>0.05)$ so that $\mathrm{HO}$ is accepted (Table 2). The result indicates that the model is acceptable. Hypothesis testing can be done because there is no significant difference between the model and its observation value.

Table 2. Overall percentage and Hosmer \& Lemeshow test result

\begin{tabular}{|c|c|c|c|c|c|}
\hline & & & \multicolumn{2}{|c|}{ Predicted } & \multirow{2}{*}{$\begin{array}{c}\text { Percentage } \\
\text { Correct }\end{array}$} \\
\hline & & & $\begin{array}{c}\text { Don't } \\
\text { Choose }\end{array}$ & Choose & \\
\hline & & Choose & 127 & 0 & 100,0 \\
\hline Step 0 & Observed & $\begin{array}{c}\text { Don't Choose } \\
\text { Overall } \\
\text { Percentage }\end{array}$ & 125 & 0 & $\begin{array}{c}, 0 \\
50,4\end{array}$ \\
\hline & & Don't Choose & 122 & 5 & 96,1 \\
\hline Step 1 & Observed & $\begin{array}{c}\text { Choose } \\
\text { Overall } \\
\text { Percentage }\end{array}$ & 2 & 123 & $\begin{array}{l}98,4 \\
97,2\end{array}$ \\
\hline Chi-square & & Df & & & Sig. \\
\hline 6.802 & & 8 & & & 0.558 \\
\hline
\end{tabular}


Table 3. Omnibus Test

\begin{tabular}{cccc}
\hline & Chi-square & Df & Sig. \\
\hline Step & 288,720 & 10 &, 000 \\
Block & 288,720 & 10 &, 000 \\
Model & 288,720 & 10 &, 000 \\
\hline
\end{tabular}

Table 2 shows that in Step 0, the Overall Percentage value is $50.4 \%$. Meanwhile, at step 1 , where the independent variable was included in the model, the Overall Percentage value was $97.2 \%$. So, the model is said to be good because it has a higher overall percentage step $1(97.2 \%)$ than overall step 0 (50.4\%).

The chi-square value $(x 2)$ of $288,720>x 2$ table on Degree of Freedom 10 is 18.307 or with a significance of $0.000(<0.05)$, indicating that the addition of independent variables can have a real effect on the model, or in other words, the model is declared fit.

The test results show that there is a significant effect of income, price, location, facilities, and religiosity on the probability of choosing a PHC on a Sharia Property Developer, which is indicated by a Chi-Square $p$-value of $0.000(<0.05)$ or a Chi-Square value $(x 2)$. count 288,720> Chi-Square $(X 2)$ table 18,307.

The Negelkerke R Square value is 0.909 , and Cox \& Snell R Square is 0.682 , indicating that the ability of the independent variable to explain the dependent variable is 0.909 or $90.9 \%$, and there are $100 \%-90.9 \%=9.1 \%$ other factors outside the model which describes the dependent variable.

All independent variables, price, and religiosity variables are significant to the probability of consumers choosing a Sharia Property Developer PHC (see Table 5). The coefficient of the price variable shows a negative sign of -0.673 . The more expensive the consumer's perception is the consumer will not choose a Sharia Property Developer PHC. The coefficient of religiosity variable is also negative at $-1,116$, which means that the more haram consumer perceptions are, the consumers will not choose a Sharia Property Developer PHC.

For variables other than price and religiosity, although not significant, the sign of the coefficient of each variable was as expected.

Table 4. Cox \& Snell R Square dan Nagelkerke R Square

\begin{tabular}{|c|c|c|}
\hline-2 Log likelihood & Cox \& Snell R Square & Nagelkerke R Square \\
\hline $60.610^{a}$ & 0.682 & 0.909 \\
\hline
\end{tabular}


Table 5. Logit Regression Results

\begin{tabular}{cclllll}
\hline & B & S.E. & Wald & df & Sig. & \multicolumn{1}{c}{ Exp(B) } \\
\hline Boyolali & 17,923 & 40192,885 &, 000 & 1 & 1,000 & 60788375,265 \\
Magelang & 15,103 & 40192,885 &, 000 & 1 & 1,000 & 3623873,951 \\
Pati & 14,025 & 40192,885 &, 000 & 1 & 1,000 & 1232904,809 \\
Semarang & 15,798 & 40192,885 &, 000 & 1 & 1,000 & 7257908,611 \\
Wonosobo & 18,524 & 40192,885 &, 000 & 1 & 1,000 & 110919531,806 \\
Income &, 055 & 1,038 &, 003 & 1 &, 958 & 1,057 \\
Price &,- 673 &, 153 & 19,304 & 1 &, 000 &, 510 \\
Location &,- 079 &, 155 &, 261 & 1 &, 609 &, 924 \\
Facilities &, 300 &, 238 & 1,582 & 1 &, 208 & 1,349 \\
Religiosity & $-1,116$ &, 286 & 15,194 & 1 &, 000 &, 328 \\
Constant & $-2,131$ & 40192,885 &, 000 & 1 & 1,000 &, 119 \\
\hline
\end{tabular}

*significant by $\alpha=10 \%$; ** significant by $\alpha=5 \%$

Regression Equation :

$$
\begin{aligned}
Y_{i}= & -2,131+17,923 \text { Boyolali }+15,103 \text { Magelang }+14,025 \text { Pati } \\
& +15,798 \text { Semarang }+18,524 \text { Wonosobo }+0,055 \text { Income - } \\
& \text { 0,673Price - 0,079Location }+0,300 \text { Facilities - } \\
& \text { 1,116Religiosity }+\varepsilon
\end{aligned}
$$

The income variable has a positive coefficient of 0.055 , indicating a data pattern directly proportional to the greater the income, the greater the probability of consumers choosing a Sharia Property Developer PHC. The coefficient value of the negative location variable is -0.079 and is not significant. These results indicate that the consideration of distance is not a factor in the probability of consumers choosing a Sharia Property Developer PHC. The facility variable coefficient is also positive 0.300 but not significant. These results indicate that the more complete the facility, the greater the probability of consumers choosing a Sharia Property Developer PHC.

For the regional dummy variable, the results are not significant to the probability of consumers choosing a Sharia Property Developer PHC, but when viewed from the respective coefficient values for the Wonosobo area $(18,524)$, Boyolali $(17,923)$, Semarang $(15,798)$, Magelang $(15,103)$ and Pati $(14,025)$. These results indicate consumer interest in each district / city in Central Java. It can be seen from the dummy areas that affect the intercept / starting point of the regression line. Boyolali $(17,923+(-2,131)=15,792)$; Magelang $(15,103)+(-2,131)=12,972)$; Starch $(14,025+(-2,131)$ $=11,894)$; Semarang $(15,798+(-2,131)=13,667)$; Wonosobo $(18,524+(-2,131)=16,393($ Table 5$)$. 
The effect of income on the probability of consumer decision to choose a public house credit from a sharia property developer

The income variable has a positive coefficient of 0.055 , indicating a data pattern directly proportional to the increase in income, and the more respondents choose Sharia Property Developer PHC. The income variable has a significance value of 0.958, which means that it does not significantly affect the probability of a consumer's decision to choose a Sharia Property Developer PHC because it is more than 0.05 .

The effect of price perception on the probability of consumer decision to choose a public house credit from a sharia property developer

Based on the results of the hypothesis test, it can be explained that the price variable has a significant negative effect of -0.673 on the probability of consumers choosing a Sharia Property Developer $\mathrm{PHC}$, meaning that the more expensive the respondent's perception of the Sharia Property Developer PHC, the more reluctant to choose it.

\section{The effect of location perception on the probability of consumer decision to choose a public house credit from a sharia property developer}

The coefficient of the location variable has a significance value of 0.609 , greater than the significance value of 0.05 . Then the location variable has no significant effect on the willingness to choose a Sharia Property Developer PHC. This result means that the consideration of distance is not a factor in the probability of selecting a Sharia Property Developer PHC.

The effect of perceived facilities on the probability of consumer decision in choosing public house credit from a sharia property developer

This thesis research shows that the facility variable coefficient is also positive, which shows the data pattern that the more complete the facilities, the more likely it is to choose a Sharia Property Developer PHC. The significance value of 0.208 is more than the significance value of 0.05 , which means that there is no significant or no effect of facilities on the probability of consumers choosing a Sharia Property Developer PHC.

The effect of perception of religiosity on the probability of consumer decision in choosing a public house credit from a sharia property developer 
The religiosity variable has a significant negative effect on the probability of choosing a PHC on a Sharia Property Developer. The coefficient value of the price variable is $-1,116$, which means that as the consumers perceive the PHC as haram (forbidden), the more likely the consumer does not choose PHC on Islamic Property Developer. In fact, $56.3 \%$ of consumers consider PHC on Sharia Property Developers to be halal, $22.2 \%$ believe it as syubhat, and $21.4 \%$ consider it haram. Almost half of the consumers perceive syubhat and haram, so the perception of halal here still needs to be considered. So even though more consumers perceive it as halal, consumers have the probability of not choosing a Sharia Property Developer PHC.

As for the reasons for consumers, namely: "because SPD does not have a relationship (accessibility) with Islamic banking. As a result, consumers experience difficulties related to funding from Islamic banking as a third party. In addition, for consumers who do not have collateral (collateral), they will experience more difficulties, even though the Sharia Property Developer PHC can use the house certificate in the PHC. However, the level of consumer concern about the security of the certificate is still very high ". That way, if it is concluded, there are findings that any factors that influence consumers to choose Sharia Property Developer PHC in Central Java will still return to the main factor, namely price.

\section{Conclusion}

The price variable has a significant negative effect on the probability of choosing a PHC on a Sharia Property Developer. The coefficient value of the price variable is -0.673 means that the more expensive consumer perceptions are, the consumers do not choose $\mathrm{PHC}$ on Sharia Property Developers. Consumers who perceive high prices on the Sharia Property Developer PHC are 75.8\%. Suppose a conclusion is drawn based on research problem research. In that case, the decrease in the number of sales of PHC houses to Islamic Property Developers is caused by perceptions of the high price.

The religiosity variable has a significant negative effect on the probability of choosing a PHC on a Sharia Property Developer. Based on research problems, the decrease in the number of PHC home sales to Sharia Property Developers is caused by the 
perception of haram. 56.3\% of consumers consider PHC on Sharia Property Developers to be halal, $22.2 \%$ consider it syubhat, and $21.4 \%$ consider it haram. Almost half of the consumers perceive syubhat and haram, so the perception of halal here still needs to be considered. So even though more consumers perceive it as halal, consumers have the probability of not choosing a Sharia Property Developer PHC.

Income, location, and facilities variables do not significantly affect the probability of choosing a PHC on a Sharia Property Developer. Wonosobo Regency is the region with the greatest probability of choosing a PHC on a Sharia Property Developer compared to Boyolali, Pati, Magelang, and Semarang City Regencies. Meanwhile, Pati Regency is the region with the least probability of choosing a PHC as a Sharia Property Developer.

\section{References}

Amri, M. A. (2018). Faktor-Faktor Yang Mempengaruhi Keputusanan Nasabah Bank OCBC NISP Medan Dalam Pemilihan PHC Konvensional Dan Syariah. At-Tawassuth, III(2), 379-398.

BPS. (2018). Proyeksi Penduduk Indonesia 2015-2045 Hasil SUPAS 2015 - 2045. (B. K. P. B. Subdirektorat Statistik Demografi, Ed.). Jakarta: Badan Pusat Statistik. https://doi.org/2101015

Budi, M. (2009). Analisis Permintaan Rumah Sederhana Di Kota Semarang. Jurnal Bisnis Dan Ekonomi (JBE), 16(2), 126-139. https://doi.org/ISSN: 1412-3126

Djaja, S. (2010). Analisis pengaruh perilaku konsumen dalam pengambilan keputusan. Wacana, 13(1), 58-69. https://doi.org/ISSN. 1411$\underline{0199}$

Fifilia, S. W. (2009). Analisis Pengaruh Produk, Harga, Promosi, Dan Lokasi Terhadap Keputusan Pembelian Rumah (Studi pada Perumahan Graha Estetika Semarang). Tema, 6(2), 159169.https://doi.org/ISSN : 1693-9727

Hidayat, G. (2017). Analisis Faktor-Faktor Yang Mempengaruhi Keputusan Permintaan PHC Pada Bank Syariah Di Kabupaten Sumedang. Coopetition, VIII(2), 129-137.

Ismail, S. (2014). Selection Criteria For Islamic Home FInancing In Malaysia. International Journal of Business and Society, 15(1), 97110. 
Jumiati, E. (2017). Pengaruh Harga Terhadap Keputusan Konsumen Membeli Rumah Tipe 36 Pada CV. Perdana Laju Mandiri Di Gunung Manggis Kota Banjarbaru. Jurnal Scientific, 1(1), 1-20.

Khoirudin, R. (2017). Determinan Yang Mempengaruhi Jumlah Permintaan Kredit Pemilikan Rumah di Indonesia Determinants Affecting The Number of Demand For Mortgages in Indonesia. Ekonomikawan: Jurnal IImu Ekonomi Dan Studi Pembangunan, 17(2), 105-120. https://doi.org/ISSN : 2598-0157

Luthfi, A. (2017). Analisis pengaruh bauran pemasaran dan pelayanan terhadap keputusan pembelian pada perumahan green tegal gede residence 1. Prosiding Seminar Nasional Dan Call For Paper Ekonomi Dan Bisnis (SNAPER-EBIS 2017), 477-485.

Mahardini, I., \& Woyanti, N. (2012). Analisis Pengaruh Harga, Pendapatan, Lokasi, Dan Fakultas Terhadap Permintaan Rumah Sederhana (Studi Kasus Perumahan Puri Dinar Mas Semarang). Dliponegoro Journal Of Economics, 1(2009), 1-11.

Primarianto, A., Yuliati, L. N., \& Affandi, M. J. (2018). Pengaruh Motivasi, Marketing Mix dan Konsep Diri Terhadap Keputusan Pembelian Rumah Baru di Perumahan Bukit Cimanggu City Bogor. Jurnal Aplikasi Bisnis dan Manajemen (JABM), 4(3), 454-454.

Radiah, D. S. (2014). Analisis Faktor-Faktor Yang Mempengaruhi Keputusan Nasabah Mengambil PHC Pada Bank Mandiri Cabang Utama Samarinda. eJournal IImu Administrasi Bisnis, 2(1), 15-29.

Sugiyono (2013). Metode Penelitian Bisnis (Pendekatan Kuantitatif, Kualitatif, dan R\&D), Bandung: CV. Alfabeta

Suprajang, S. E. (2011). Faktor-Faktor Yang Mempengaruhi Konsumen Mengambil Keputusan Membeli Rumah (Studi Pada Perumahan Wisma Indah Kota Blitar). Jurnal Kompilek, 3(2), 29-39. https://doi.org/2088-6268

Wardani, D. dan D. P. (2013). Pengaruh Bauran Promosi Terhadap Keputusan Pengambilan Produk Pembiayaan PHC Platinum iB Pada Bank X Syariah Cabang Harmoni-Jakarta. Jurnal Ekonomi Dan Bisnis, 12(1), 1-10.

Yuliati, L. (2018). Pengaruh Motivasi, Marketing Mix dan Konsep Diri Terhadap Keputusan Pembelian Rumah Baru di Perumahan Bukit Cimanggu City Bogor, 4(3), 454-463. https://doi.org/10.17358/jabm.4.3.454 
Nurzahroh Lailyah

JIEMB | 80

Journal of Islamic Economics, Management, and Business-Vol 2. No.2 (2020) 